\title{
Article
}

http://dx.doi.org/10.11646/phytotaxa.267.1.3

\section{Stipa dickorei sp. nov. (Poaceae), three new records and a checklist of feather grasses of China}

\author{
MARCIN NOBIS ${ }^{1}$, AGNIESZKA NOBIS ${ }^{1}$, EWELINA KLICHOWSKA ${ }^{1}$, ARKADIUSZ NOWAK ${ }^{2,3}$, SYLWIA \\ NOWAK $^{2} \&$ POLINA D. GUDKOVA ${ }^{4}$ \\ ${ }^{1}$ Department of Plant Taxonomy, Phytogeography and Herbarium, Institute of Botany, Jagiellonian University, Kopernika 27, PL-31- \\ 501 Kraków, Poland; \\ ${ }^{2}$ Laboratory of Geobotany and Plant Conservation, Department of Biosystematics, Opole University, Oleska 48, PL-45-052 Opole, \\ Poland; \\ ${ }^{3}$ Department of Biology and Ecology, University of Ostrava, 71000 Ostrava, Czech Republic \\ ${ }^{4}$ Laboratory of Systematics and Phylogeny of Plants, Institute of Biology, Tomsk State University, 36 Lenin Prospekt, Tomsk, 634050 \\ Russia \\ Corresponding author:m.nobis@uj.edu.pl
}

\begin{abstract}
Stipa dickorei sp. nov. from the Western Tibetan Plateau (China) is described. The new species is morphologically similar to $S$. regeliana, but they differ from each other in the length of ligules of vegetative shoots. Stipa dickorei is also similar to S. aliena, however they differ in the shape of panicle, which is contracted with straight branches in $S$. dickorei, and lax with flexuous branches in $S$. aliena. Images of macromorphological and micromorphological structures of the new taxon are provided. Additionally, new records of S. borysthenica, S. richteriana, and S. zalesskii, species not listed in the recent Flora of China, as well as a checklist of Chinese feather grasses are also presented.
\end{abstract}

Key words: distribution, feather grasses, lemma micromorphology, macromorphology, Stipa, taxonomy

\section{Introduction}

The genus Stipa Linnaeus (1753: 78) is one of the most species rich grass genera in China but the number of taxa and taxonomic level at which they were treated, differs among taxonomic publications and editions of the Chinese Floras. For instance, Kuo \& Sun (1982) listed 27 species and 4 taxa at variety level while the same authors, a few years later (Kuo \& Sun 1987), listed 23 species and 6 varieties. In the Nineties, Lu \& Wu (1996) listed 32 species and 5 taxa at variety level, and in the last edition of the Flora of China, Wu \& Phillips (2006) gave 23 species, 1 subspecies and 5 taxa at variety level. The differences in the number of species, in particular publications regard mainly such species like: S. basiplumosa Munro ex Hooker (1896: 229), S. himalaica Roshevitz (1924: 11), S. hohenackeriana Trinius \& Ruprecht (1842: 80), S. pennata Linnaeus (1753: 78), S. richteriana Karelin \& Kirilov (1841: 862), S. stapfii Roshevitz (1924: 11), S. szovitsiana Trinius \& Ruprecht (1842: 77) Grisebach (1852: 450) and S. turgaica Roshevitz (1949: 22), as well as those which are either regarded as varieties or raised to the level of subspecies or species. All of the taxa mentioned above were listed by $\mathrm{Lu} \& \mathrm{Wu}$ (1996), but omitted or regarded as conspecific with other taxa by Wu \& Phillips (2006). However, some of these taxa mentioned above were reported from China also by other authors, e.g., occurrence of $S$. himalaica in China was confirmed by Tzvelev (1968), Dickoré (1995) and Nobis et al. (2013); $S$. hohenackeriana was reported by Tzvelev (1968), whereas S. pennata by Tzvelev (1968) and Gonzalo et al. (2013). Herbarium specimens of this species (revised by us) are preserved at LE. From the remaining taxa, S. basiplumosa [三S. subsessiliflora (Ruprecht 1869: 35) Roshevitz (1915: 50) subsp. basiplumosa (Munro ex Hook.f.) Cui (1996: 309), $\equiv$ S. subsessiliflora var. basiplumosa (Munro ex Hook.f.) Kuo \& Sun (1987: 282)] should be treated as a legitimate species as it clearly differs from $S$. subsesiliflora in longer $(9.5-13.5$ vs. 6-8.5 mm) glumes, which are the widest in the lower $1 / 3$ of their length vs. in the middle part of their length, respectively (Nobis et al. 2015a). Stipa szovitsiana is a synonym of $S$. arabica Trinius \& Ruprecht (1842: 77) whereas $S$. turgaica is currently sunk within $S$. arabica as the variety, S. arabica var. turgaica (Roshev.) Tzvelev (1976: 584) as it differs by having pubescent leaves and sheaths. 
This is similar to the case of S. penicillata Handel-Mazzetti (1936: 226), where specimens having pubescent culms and leaves are treated as S. penicillata var. hirsuta Kuo \& Sun (1984: 89). Although S. hohenackeriana is absent in Wu \& Phillips (2006), it was mentioned by them under $S$. lessingiana Trinius \& Ruprecht (1842: 79) with the statement that S. hohenackeriana was reported from Xinijang. Stipa stapfii is currently regarded as a synonym of $S$. hohenackeriana (Freitag 1985). Stipa richteriana, on the other hand, is a native and permanent element of the Chinese flora collected from few localities in western China (see chapter New records, below). Some other taxa, treated in the Flora of China (Wu \& Phillips 2006) at the level of variety, such as S. klemenzii Roshevitz (1924: 12) and S. krylovii Roshevitz (1929: 379) are currently regarded as distinct species (Tzvelev 1976, Lomonosova 1990, Nobis 2014, Nobis et al. 2016b).

In a result of previous field investigation in poorly explored regions of China and revision of herbarium material collected from the country, species unlisted so far in the Flora of China were recorded and new taxa were described. Only recently, Stipa gracilis Roshevitz (1916: 151), S. klimesii Nobis (in Nobis et al. 2014: 174 [166]) and S. macroglossa Smirnov (1924: 47) subsp. kazachstanica (Kotukhov 1994: 104) Nobis (2013: 1055) were recorded as components of the Chinese flora (Nobis 2013, Nobis et al. 2013, 2015b) and S. albasiensis Zhao \& Guo (2011: 522) was described from China.

During revision of herbarium material belonging to Stipa we came across specimens belonging to Stipa borysthenica Klokov ex Prokudin (1951: 25), S. richteriana and S. zalesskii Wilenskii (1921: 41), the species not mentioned in the recent Flora of China (Wu \& Phillips 2006), as well as specimens belonging to Stipa section Regelia Tzvelev (1974: 13), collected from southern China that were clearly distinguishable from the other members of this section and representing the new species, Stipa dickorei, described herein.

\section{Material and Methods}

This study is based on plant material deposited in the herbaria of B, E, FRU, GAT, GFW, GOET, IFP, KAS, KHOR, KRA, KRAM, KUN, LE, M, MOIS, MSB, MW, PE, TAD, TK, UPS, W, WA, WU. For scanning electron microscope (SEM) observation, samples were coated with gold using a JFC-1100E Ion sputter manufactured by JEOL. Micromorphological structure of the lemmas was observed and photographs taken by means of the scanning electron microscope Hitachi S-4700, at various magnifications. Lemmas (removed from mature spikelets in the middle part of the panicle) were studied from the base to the distal portions. Quantitative and qualitative characters were studied for the abaxial lemma surface. We analysed: length of long cells, length and distribution of macrohairs, shape of silica bodies, presence and shape of hooks and prickles. The pattern of hairiness of the leaves (adaxial and abaxial surface of blades from the middle part of leaves) was also studied in examined taxa and photographs were taken by means of SEM.

\section{Taxonomy}

Stipa dickorei M.Nobis, sp. nov. (Figs. 1-2)

Type:-CHINA. Xizang: E Tibet, upper Salween basin, Riwoqe—Dengqen, Da Qu, 31 ${ }^{\circ} 10^{\prime} \mathrm{N} / 96^{\circ} 10^{\prime} \mathrm{E}$, elev. ca. $4120 \mathrm{~m}$, lower alp. Kobresia turf, limestone rocks, 8 July 1994, B. Dickoré 9083 (holotype MSB-152840!, isotypes KAS! —2 sheets, KRA!).

Perennial plant, densely tufted, with a few culms and numerous vegetative shoots; culms (12-)19-40 cm tall, with $1(-2)$ node in the lower part of the culm. Leaves of vegetative shoots: sheaths glabrous or/and shortly pilose but only in the upper part near the margin and ligule; ligules membranous $(0.3-) 0.5-1.6 \mathrm{~mm}$ long, obtuse, the apex shortly ciliate and setulose on the back; blades flat or convolute, green to pale green, $12-18 \mathrm{~cm}$ long, $0.5-1.0 \mathrm{~mm}$ in diameter or up to $2.2 \mathrm{~mm}$ wide when they are flat, adaxial surface densely covered with prickles up to $0.09 \mathrm{~mm}$ long, abaxial surface glabrous, at the apex glabrous or somewhat scabrous due to short prickles and spinules. Cauline leaves: sheaths glabrous, upper sheath of culms not inflated; ligules (1.5-)2.0-3.5(-4.5) $\mathrm{mm}$ long, acute or obtuse, with very short cilia at the apex, and shortly setulose on the back; blades convolute, green or pale green, up to $10 \mathrm{~cm}$ long, adaxial surface shortly pilose, abaxial surface glabrous, slightly scabrous at the apex due to short prickles and spinules. Panicle contracted, (5-)10-16 cm long and 1-2 cm wide, with (8-)12-17 spikelets, exerted, branches erect, glabrous or somewhat setulose below spikelets. Glumes subequal, pale green to somewhat purple, lower glume 10.5-13.0 $\mathrm{mm}$ long, upper glume 
10.0-12.5 mm long, lanceolate, tapering into a delicate hyaline apex, glabrous on dorsal line. Anthecium 8.0-9.2 $\mathrm{mm}$ long, $0.7-0.9 \mathrm{~mm}$ wide. Callus $1.0-1.3 \mathrm{~mm}$ long, sharply pointed, densely long-pilose, hairs $0.5-0.9 \mathrm{~mm}$ long; base of callus dorsally flattened and long protruding, peripheral ring $0.25-0.30 \mathrm{~mm}$ in diameter, scar broadly elliptic. Lemma pale green, on dorsal surface covered by numerous hooks and scattered ascending hairs $0.4-0.7 \mathrm{~mm}$ long, top of lemma with coronula of hairs $0.4-1.0 \mathrm{~mm}$ long. Awn 20-26(-32) mm long, bigeniculate; column 5-7 mm long, twisted, 0.2(-0.3) $\mathrm{mm}$ wide, green or straw-coloured, pilose, hairs $(0.2-) 0.5-1.0(-1.3) \mathrm{mm}$ long, gradually decreasing in length towards the geniculation; the middle segment of the awn 3-5 mm long, pilose, hairs (0.1-)0.2-0.3 mm long; seta straight, green or purple, $11-15 \mathrm{~mm}$ long, hairs on seta $0.1-0.2 \mathrm{~mm}$ long. Palea equal to lemma in length, with scattered hairs on dorsal surface. Anthers yellow or purple, glabrous, 3-4 mm long.

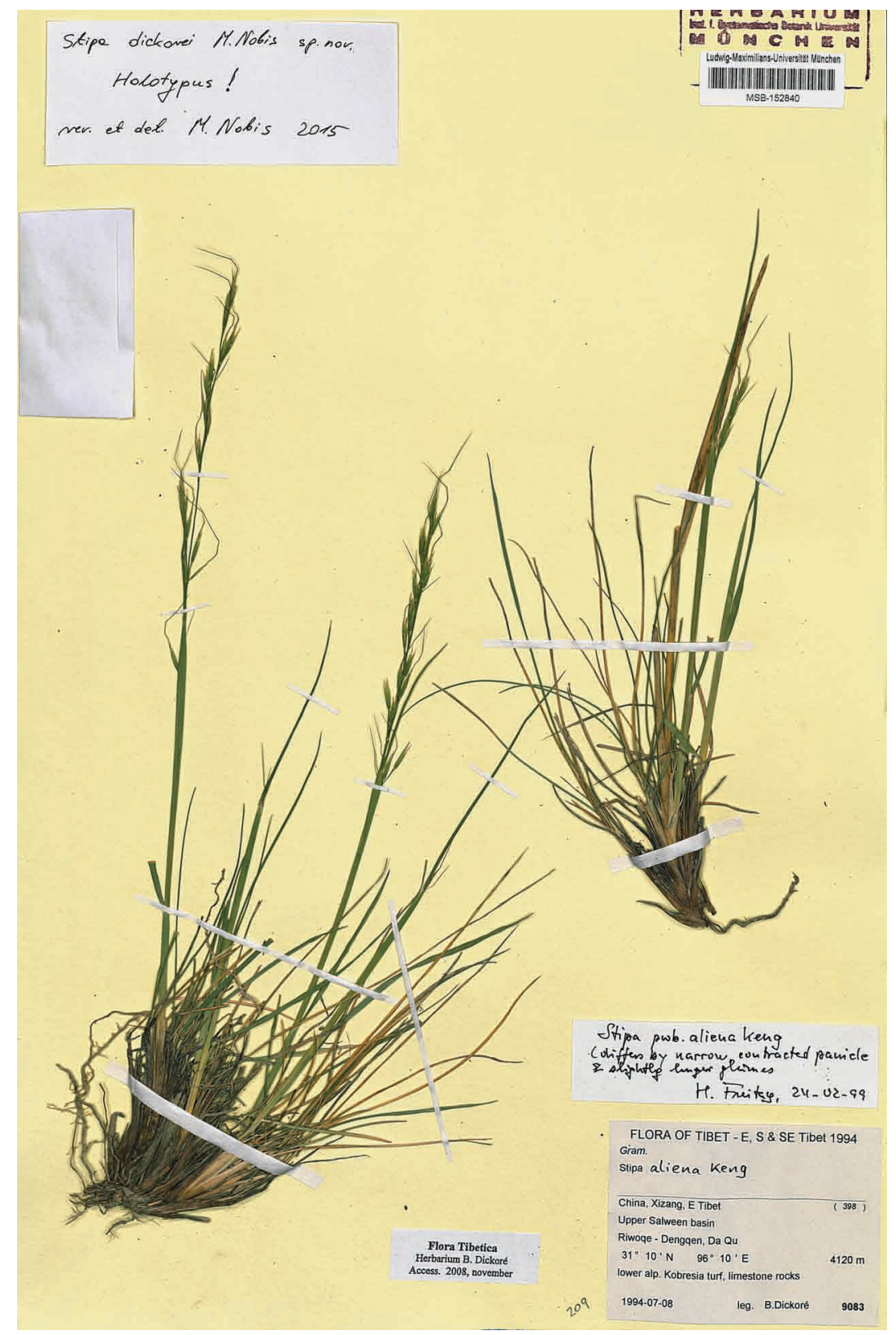

FIGURE 1. Holotype of Stipa dickorei.

Distribution and ecology:-Stipa dickorei is known from the eastern part of the Qinghai-Tibetan Plateau in southwestern China. It is probable that the species occupies neighbouring areas, where similar habitat occurs. The species grows in high mountain alpine swards, between elevation range of 3700 to $4300 \mathrm{~m}$.

Etymology:-The species epithet honors the collector Dr. Wolf Bernhard Dickoré, the eminent German botanist, researcher of the flora and vegetation of Central Asian mountains.

Additional specimens studied (paratype):-CHINA. Qinghai: Nangqên Xian, Bêca Xiang, just W of Bêca Forest Station, on road to the Bas Qu, SE of Bêcaka, 31 ${ }^{\circ} 53^{\prime} \mathrm{N} / 96^{\circ} 32^{\prime} \mathrm{E}, 3750 \mathrm{~m}$, on large rocks, slope below limestone 
cliffs with remnant Juniperus woodland, rock outcrops frequent, 9 September 1996, T.N. Ho, B. Bartholomew, M. Watson, M. Gilbert 3024 (PE-202793!).

Similar species:-Because of its contracted panicle, Stipa dickorei is morphologically very similar to $S$. regeliana Hackel (1884: 130). However, the two species differ from each other in the character of ligules of vegetative shoots, which in $S$. dickorei are always shorter $(0.3-1.6$ vs. $4-6 \mathrm{~mm})$ as well as by glabrous vs. slightly scabrous leaves, respectively.

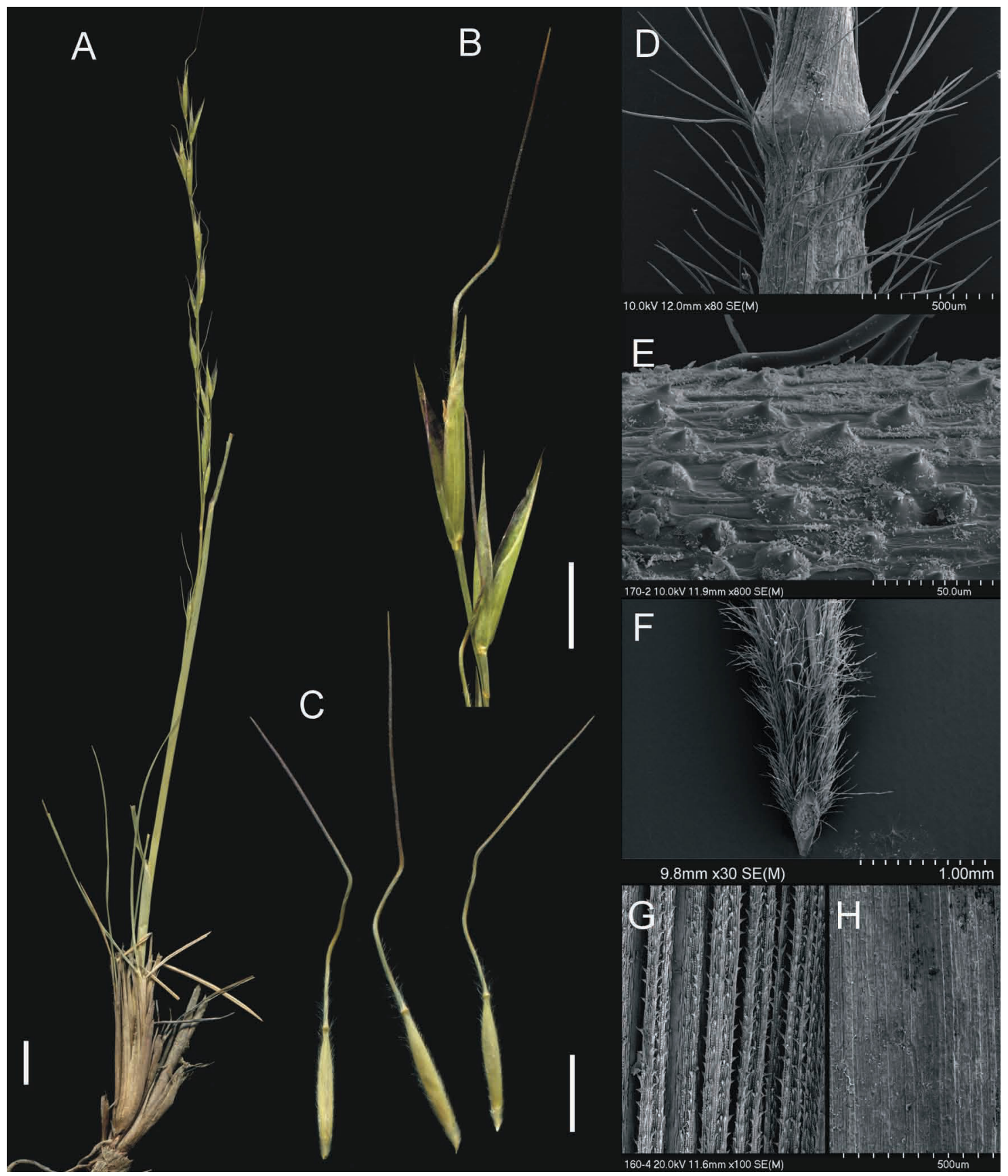

FIGURE 2. Selected morphological characters of Stipa dickorei. A. General habit. B. Spikelets. C. Anthecia with awns. D. Lemma apex with basal part of the awn. E. Micromorphological structure of the lemma epidermis (lateral view). F. Callus. G. Adaxial surface of leaves. H. Abaxial surface of leaves. Scale bars: A: $1 \mathrm{~cm}, \mathrm{~B}-\mathrm{C}: 5 \mathrm{~mm}$.

Stipa dickorei is also similar to $S$. aliena Keng (1941a: 74). These two species differ in the shape of their panicle which, in $S$. dickorei is contracted with straight, glabrous or somewhat setulose branches, whereas in $S$. aliena the panicle is lax with flexuous branches that are more or less densely setulose (hairs $0.3-0.6 \mathrm{~mm}$ long, sometimes present only below the glume). Additionally, $S$. dickorei has somewhat longer ligules of the vegetative leaves $[(0.3-) 0.5-1.6$ vs. 0.1-0.5(-0.9) $\mathrm{mm}$, respectively].

Stipa aliena is a polymorphic and variable taxon, particularly in the length of its culms, glumes, anthecia, calluses, 
awns, as well as in the number of spikelets per panicle (Nobis et al. 2015a). Within the taxon, the variety S. aliena var. macrocarpa (Martinovský 1970: 163) Nobis (in Nobis et al. 2015a: 238) has been distinguished, which differs from $S$. aliena var. aliena by having longer anthecia (9-12 vs. $6.5-8.5 \mathrm{~mm})$ and slightly longer awns (23-30 vs. 15-26 mm). At the end of the last century, S. rohmooiana Noltie (1999: 287) was described from Sikkim. This taxon is morphologically very close to $S$. aliena, what was stressed also by Noltie (1999). Based on the description, $S$. rohmooiana differs from $S$. aliena generally by lower culms $(3.5-12 \mathrm{~cm})$ and smaller number of spikelets (5-7 non ca. 20) per panicle (Noltie 1999). However, during our revision of Chinese specimens of S. aliena, specimens with culms 5-60(-84) cm tall and panicles with (2-)5-14(-20) spikelets were frequently observed. Probably, growth of plants from Sikkim could be limited by harsh conditions at the mountainous locality (elevation ca. $5000 \mathrm{~m}$.), where these specimens were collected by Rohmoo in September 1912. Similar modifications in the habit of plants is observed for other high-mountains feather grasses, like S. glareosa Smirnov (1929a: 12), S. tianschanica Roshevitz (1916: 149), S. lipskyi Roshevitz (1916: 153), S. zeravshanica Nobis (in Nobis et al. 2013: 667) or Ptilagrostis concinna (Hooker 1896: 230) Roshevitz (1934: 75), which at higher elevations, have smaller culms and sometimes reduced number of spikelets. Thus, we treat $S$. rohmooiana as conspecific with $S$. aliena.

Taxonomic synopsis of Stipa sect. Regelia:-Having awn setas with hairs up to $0.3 \mathrm{~mm}$ long as well as plumose columns with hairs up to $1.5 \mathrm{~mm}$ long, the new species described here is a typical member of the section Regelia, which currently comprises three species, namely:

\section{Stipa regeliana Hack.}

Type:-[KYRGYZSTAN]. Issyk-kul, Musart, 2300-2650 m, August 1877, Regel (holotype W!).

$\equiv$ Achnatherum regelianum (Hack.) Tzvelev (2012: 22)

= Stipa purpurascens Hitchcock (1930a: 95). Type:-CHINA. Gansu: south of Sining, in the La Che Tze Mountains, elev. 3350 to 3900, R.C. Ching 686 (US-1245701).

\section{Stipa aliena Keng}

\subsection{Stipa aliena var. aliena}

Type:-CHINA. Gansu: Labrang, grassy swampy places, elev. 3000 m, 17 October 1934, C.W. Yao 502 [Herbarium Biological Laboratory, the Science Society of China, N 57946] (isotype PE-639926!)

= Stipa smithii Martinovský (1970: 162) nom. hom. illeg., non S. smithii Hitchcock (1930b: 382). Type:-CHINA. Sichuan [Sina, prov. Sze-ch'uan]: reg. bor--occid., Sankar-von-mâ, c. 45 km bor--orient. versus in prato, c. 4100 m, 2 September 1922, leg. Harry Smith, Plantae sinenses 4287 (holotype UPS!, isotypes UPS!, PE!, LD)

= Stipa rohmooiana Noltie, syn. nov. Type:-Sikkim: Chugya, elev. c. 4900 m, 12 September 1912, Rohmoo 277 (holotype E!, isotype $\mathrm{K} !)$.

\subsection{Stipa aliena var. macrocarpa (Martinovský) M.Nobis}

Basionym:-Stipa smithii Martinovský var. macrocarpa Martinovský (1970: 163). Type:-CHINA. Sichuan: reg. bor.-occid., Tsipula, in prato alpino graminoso, alt. c. 4000 m, 2 August 1922, leg. Harry Smith, Plantae sinenses 4148 (holotype UPS!, isotypes PE2029699!, LD, MOIS!).

\section{Stipa dickorei M.Nobis}

Micromorphological variation:-The general pattern of the lemma micromorphology in Stipa dickorei is typical for the genus Stipa (cf. Barkworth \& Everett 1987, Nobis 2013, 2014, Nobis \& Nobis 2013, Nobis et al. 2013, 2014, 2015a, 2016a) (Fig. 2E). Fundamental long cells are elongated, rectangular to more or less square in shape. The side walls of the long cells are raised and undulate. Silica bodies are frequent, reniform to oblong or ovate, whereas cork cells are sparse or absent. Hooks are frequent, oriented towards the lemma apex, whereas prickles are sparse and present mostly near the apex of the lemma (Fig. 2D-E). Macrohairs are frequent on the whole surface of the lemma. They are straight, (0.1-)0.4-0.7 mm long or geniculately bent near the base, cylindrical and/or string-like twisted, with bulbous base and needle-like apex. The adaxial surface of leaves of the vegetative shoots (Fig. 2G) is ribbed and covered by frequent prickles and papillae as well as less frequent stomata and rectangular to slightly 8-like constricted silica bodies. Abaxial surface of leaves is glabrous (Fig. 2H), with frequent elongated long cells and rounded to rectangular silica bodies. 


\section{New records of Stipa for the Flora of China}

During revision of Chinese material of Stipa, we came across on three species which are absent in the recent Flora of China (Wu \& Phillips 2006). Data regarding these species are presented below.

Stipa borysthenica Klokov ex Prokudin

Type:-UKRAINE. Lugov forest country house, Tyasmin, Aleks, u., 18 May 1911, I. Paczoski (lectotype selected by Tzvelev, LE!)

Stipa boryshtenica is a widely distributed taxon ranging from central Europe to central Asia (Tzvelev 1976, Martinovský 1980, Conert 1998, Gonzalo et al. 2013) and is here reported for the first time from China. Having the ventral line of hairs at the anthecium at the distance of (1.6-)4.2-6.1(-7.7) $\mathrm{mm}$ not reaching the base of awn and almost glabrous to slightly scabrous vegetative leaves, S. boryshtenica is close to $S$. pennata, however they differ by having callus base narrowly cuneate vs. pyriform, callus (3.4-)3.7-4.2(-4.6) vs. (2.4-)2.8-3.25(-3.75) $\mathrm{mm}$ long, upper cauline leaves (22-)36-62(-125) vs. (4-)10-22(-40) $\mathrm{mm}$ long respectively (Klichowska \& Nobis 2016). These two taxa also differ in the type of habitat in which they grow. Stipa borysthenica grows generally on sandy grasslands and S. pennata grows on steppe grasslands.

Specimens studied:-CHINA. Xinjiang: Fuyun county, Tuergen, elev. 1470 m., 6 June 1959, Xinjiang Exped. 10381 (PE-707071!, PE-707072!).

\section{Stipa richteriana Kar. \& Kir.}

Type:-Eastern KAZAKHSTAN. In lapidosis mont. Arganty, 1840, Karelin 907 (lectotype selected by Tzvelev 1976, LE!)

The species is widely distributed in central Asia, mainly in Kazakhstan, western China, Uzbekistan and Afghanistan (Pazij 1968, Tzvelev 1968, 1976, Freitag 1985). The main morphological characters of this taxon include: abaxial surface of vegetative leaves glabrous and adaxial surface shortly pilose with hairs up to $0.1 \mathrm{~mm}$ long, spikelets 10-14 $\mathrm{mm}$ long, anthecium 5.5-7.5 mm long, callus $0.5-1.0 \mathrm{~mm}$ long, awn 4-8 cm long, seta straight with hairs $0.3-0.8 \mathrm{~mm}$ long. The species can be confused with Stipa bungeana Trinius (1835: 144) and S. breviflora Grisebach (1868: 82). However, it clearly differs from $S$. bungeana by its pilose vs. scabrous awn, shorter callus ( $0.5-1.0$ vs. 1-1.5 mm long) as well as different lemma indumentum. Stipa richteriana differs from $S$. breviflora by shorter awns (up to 8 vs. over $9 \mathrm{~cm}$ long) and shorter hairs on seta ( $0.3-0.8$ vs. $1-2 \mathrm{~mm}$ long).

Specimens studied:- CHINA. Xinjiang: northern slope of Eastern Tian-Shan Mts, Manas River valley, 15-20 km higher from Manas city, semidesert, 6 June 1957, Bot-expedition 644 (LE!); northern slope of Eastern Tian-Shan Mts, foreland, by the road from Tsitai (Guchen), $20 \mathrm{~km}$ from Urumchi, steppe-desert, 24 September 1957, Bot-expedition 2293 (LE!); Mongolian Altai, Koktogai settl., 7 June 1959, Bot-expedition 10409 (LE!).

\section{Stipa zalesskii Wilenskii}

Type:-KAZAKHSTAN. In the vicinity of Saratovka, southern slopes in the regions of Kalyubanov's country house, 5 June $1918, D$. Wilenskii (lectotype selected by Tzvelev (1976: 587), LE!)

Stipa zalesskii is a widely distributed taxon extending from central Europe to the central Asia (Kyrgyzstan, Kazakhstan, Russia) (Tzvelev 1976, 2012, Martinovský 1980, Freitag 1985, Conert 1998, Nobis et al. 2016b). Stipa zalesskii was reported from China by Tzvelev (1968) and Cui (1996), but it was omitted by Wu \& Phillips (2006). During revision of Stipa material at LE, we came across a specimen of the species collected from Xinjiang. This is the easternmost locality of this taxon. Stipa zalesskii belongs to the section Stipa and is easily distinguishable from other Chinese feather grasses of the section Stipa by having anthecia 17-23 mm long, ventral line of hairs on lemma reaching the base of the awn, vegetative shoots with sheaths shortly pubescent and leaves with a mixture of short and long hairs on the adaxial surface and the abaxial surface scabrous due to hard prickles with a more or less dense admixtue of spinules and/or short hairs (Nobis et al. 2016b).

Specimens studied:- CHINA. Xinjiang: Dzhungaria border zone, Dzhair Mts., Dzhair pass, by the road from Toli to Otu, high mountain feather grass steppe, 9 September 1957, A.A. Yunatov, S.I. Li, I.F. Yuan 1300 (LE!). 


\section{Checklist of feather grasses (Stipa) of China}

The genus Stipa in China comprises currently 37 species, 1 subspecies and 5 varieties distributed in the vast area of open grasslands and steppes (Tzvelev 1968, Freitag 1985, Kuo \& Sun 1987, Lu \& Wu 1996, Wu \& Wang 1999, Wu \& Phillips 2006, Zhao \& Guo 2011, Nobis 2011, 2013, 2014, Gonzalo et al. 2013, Nobis et al. 2013, 2015a, 2015b, 2016a). Because of recently new species of feather grasses were described from China and new records were encountered, we presented below in alphabetic order a checklist of Stipa occurring in China, as a supplement to the Flora of the country (Wu \& Phillips 2006).

1. Stipa albasiensis L.Q.Zhao \& K.Guo

2. Stipa aliena Keng

2a. S. aliena var. aliena $[=S$. smithii Martinovský; $=$ S. rohmooiana Noltie $]$

2b. S. aliena var. macrocarpa (Martinovský) M.Nobis [三S. smithii Martinovský var. macrocarpa Martinovský]

3. Stipa arabica Trin. \& Rupr.

3a. S. arabica var. arabica $[=$ S. arabica var. szovitsiana Trinius \& Ruprecht (1842: 77); =S. szovitsiana (Trin. \& Rupr.) Griseb.; =S. caspia Koch (1848: 440); =S. arabica subsp. caspia (K.Koch) Tzvelev (1974: 16)]

3b. S. arabica var. turgaica (Roshev.) Tzvelev [ $\equiv$ S. turgaica Roshev.]

4. Stipa baicalensis Roshevitz (1929: 380) [=S. attenuata Smirnov (1934: 338)]

5. Stipa basiplumosa Munro ex Hook.f. [ $\equiv$ S. subsessiliflora (Rupr.) Roshev. subsp. basiplumosa (Munro ex Hook.f.) D.F.Cui; $\equiv S$. subsessiliflora var. basiplumosa (Munro ex Hook.f.) P.C.Kuo \& Y.H.Sun]

6. Stipa borysthenica Klokov ex Prokudin [=S. pennata L. f. sabulosa Paczoski (1914: 112); =S. pennata subsp. sabulosa (Paczoski) Tzvelev (1973: 80); =S. sabulosa Sljussarenko (1963: 26); =S. joannis Čelakovský (1884: 318) subsp. sabulosa (Paczoski) Lavrenko (1940: 123)]

7. Stipa breviflora Griseb. [=S. aliciae Kanitz (1891: 61)]

8. Stipa bungeana Trin.

9. Stipa capillacea Keng (1941b: 100)

9a. S. capillacea var. capillacea [=S. koelzii Stewart (1945: 441)]

9b. S. capillacea var. parviflora Zhao \& Li (1994: 229)

10. Stipa capillata Linnaeus (1762: 116)

11. Stipa caucasica Schmalhausen (1892: 293)

12. Stipa consanguinea Trinius \& Ruprecht (1842: 78)

13. Stipa dickorei M.Nobis

14. Stipa glareosa P.A.Smirn. [ $\equiv$ S. caucasica Schmalh. subsp. glareosa (P.A.Smirn.) Tzvelev (1974: 20); =S. orientalis Trinius (1829: 83) var. trichoglossa Hackel (1903: 164); =S. glareosa var. langshanica Zhao (1992: 546); =S. langshanica (Y.Z.Zhao) Zhao (in Zhao \& Cao 1996: 211)]

15. Stipa gracilis Roshev.

16. Stipa grandis Smirnov (1929a: 267)

17. Stipa himalaica Roshev.

18. Stipa hohenackeriana Trin. \& Rupr. [=S. stapfii Roshev.]

19. Stipa kirghisorum Smirnov (1925: 223) [三S. pennata L. subsp. kirghisorum (P.A.Smirn.) Freitag (1985: 438)]

20. Stipa klemenzii Roshev. [ $\equiv$ S. gobica Roshev. var. klemenzii (Roshev.) Norlindh (1949: 66); $\equiv$ S. tianschanica Roshev. var. klemenzii (Roshev.) Kuo \& Sun (1987: 277)]

21. Stipa klimesii M.Nobis

21a. S. klimesii var. klimesii [=S. basiplumosa Munro ex Hook.f. var. longearistata Munro ex Hooker (1896: 229)]

21b. S. klimesii var. pubescens Nobis (in Nobis et al. 2014: 176 [168])

22. Stipa krylovii Roshev. [三S. sareptana Becker (1882: 52) subsp. krylovii (Roshev.) Cui (1996: 299); 三S. sareptana var. krylovii (Roshev.) Kuo \& Sun (1987: 275); =S. capillata L. var. coronata Roshevitz (1916: 186); =S. densiflora Smirnov (1929b: 265); $=$ S. densa Smirnov (1930: 15), =S. decipiens Smirnov (1934: 338)]

23. Stipa lessingiana Trin. \& Rupr.

24. Stipa macroglossa P.A.Smirn. subsp. kazachstanica (Kotukhov) M.Nobis [三S. kazachstanica Kotukhov]

25. Stipa mongolorum Tzvelev (1968: 57)

26. Stipa orientalis Trin.

27. Stipa penicillata Handel-Mazzetti

27a. S. penicillata var. penicillata [=S. laxiflora Keng (1941a: 73)]

27b. S. penicillata var. hirsuta P.C.Kuo \& Y.H.Sun

28. Stipa pennata $\mathrm{L}$.

29. Stipa przewalskyi Roshevitz (1920: 3 )

30. Stipa purpurea Grisebach (1868: 82)

30a. S. purpurea var. purpurea [三Ptilagrostis purpurea (Griseb.) Roshevitz (1934: 76); =Lasiagrostis tremula Ruprecht (1869: 35); =Stipa pilgeriana Hao (1938: 538)]

30b. S. purpurea var. arenosa Tzvelev (1968: 60) [三S. purpurea subsp. arenosa (Tzvelev) Cui (1996: 307)]

31. Stipa regeliana Hack. [三Achnatherum regelianum (Hack.) Tzvelev; =Stipa purpurascens Hitchc.; =Achnatherum purpurascens (Hitchc.) Keng]

32. Stipa richteriana Kar. \& Kir. [=S. voronini Krassnov (1887: 125); S. kuhitangi Drobov (1941: 537)] 
33. Stipa roborowskyi Roshevitz (1920: 1)

34. Stipa sareptana A.K.Becker

35. Stipa subsessiliflora (Rupr.) Roshev. [三Lasiagrostis subsessiliflora Ruprecht (1869: 35); 三Ptilagrostis subsessiliflora (Rupr.) Roshevitz (1934: 74)]

36. Stipa tianschanica Roshev.

36a. S. tianschanica subsp. tianschanica

36b. S. tianschanica subsp. gobica (Roshevitz 1924: 13) Cui (1996: 299) [三S. gobica Roshev.; झS. tianschanica var. gobica (Roshev.) Kuo \& Sun (1987: 277); =S. sinomongholica Ohwi (1943: 168); =S. potaninii Roshevitz (1924: 13); =S. gobica var. wulateica Zhao (1992: 546); =S. wulateica (Y.Z.Zhao) Zhao (in Zhao \& Cao 1996: 211)]

37. Stipa zalesskii Wilenskii $[=$ S. rubens Smirnov (1925: 231); =S. rubentiformis Smirnov (1928: 115); =S. maeotica Klokov \& Osychnyuk (1976: 60); =S. smirnovii Martinovský (1975: 260)]

Notes: During revision of the herbarium material preserved at MSB, PE and KUN, we found numerous specimens of Stipa bhutanica Noltie (1999: 289), collected from Yunnan, Sichuan and Xizang provinces [selected specimens studied: Yunnan, the mountain behind Laotanfang, Hongtudi town, Gongchuan District, Kunming, 2605'931'N/102 '54'579'"E, 3400 m a.s.1., alpine meadow, 1 August 2008, Peng Hua, Liu Ende, Xiang Jianyuing et al. 9240 (KUN!, KUN-918490!); Xizang, E Tibet, Niingjing Shan, Mekong (Lancang) tributary, W of Markham (Gartong), above Camp 2, $29^{\circ} 41^{\prime} \mathrm{N} / 98^{\circ} 30^{\prime} \mathrm{E}, 4300 \mathrm{~m}$ a.s.l., subalpine+lower alp. turf, Rhododendron dwarf-scrub, Picea forest at tree line, 1 July 1994, B. Dickoré 8628 (MSB-152870!)]. Occurrence of this species in China was recently also reported from numerous localities by Zhang et al. (2016, unpubl). The species was described and up to date known only from Bhutan (Noltie 1999). In China, it was misidentified mainly as $S$. subsessiliflora, S. basiplumosa and S. regeliana, however, $S$. bhutanica differs from all of these mentioned above taxa by having a short blind callus, unigeniculate awns and clearly unequal lemma and palea. Because the lemma epidermal pattern of this species is typical rather for Ptilagrostis not for Stipa (Nobis \& Nobis 2013, Nobis 2013, Nobis et al. 2016a), we decided to not included this species into the given above checklist. The taxon should be transferred to the genus Ptilagrostis as P. bhutanica (M. Nobis unpubl.), further researches are needed in this case.

\section{Acknowledgments}

We would like to express our gratitude to the curators of B, E, FRU, GAT, GFW, GOET, IFP, KAS, KHOR, KRA, KRAM, KUN, LE, M, MOIS, MSB, MW, PE, TAD, TK, UPS, W, WA, WU for making the collections of the genus Stipa available for study. We are very thankful to the Reviewer(s) for his all comments and improvements to the previous version of the paper. The research was funded by the National Science Centre, Poland based on the decision no. DEC-2013/09/B/NZ8/03287.

\section{References}

Barkworth, M.E. \& Everett, J. (1987) Evolution in the Stipeae: identification and relationships of its monophyletic taxa. In: Soderstrom, T.R., Hilu, K.W., Campbell, C.S. \& Barkworth, M.E. (Eds.) Grass systematics and evolution. Smithsonian Institution Press, Washington, DC, pp. 251-264.

Becker, A. (1882) Die steinbildungen, die staphyliniden und neue pflanzenentdeckungen bei Sarepta. Bulletin de la Société Impériale des Naturalistes de Moscou 57: 48-53.

Conert, H.J. (Ed.) (1998) Gustav Hegi Illustrierte Flora von Mitteleuropa, 1 (3), Spermatophyta: Angiospermae: Monocotyledones, 1 (2) Poaceae. Parey Buchverlag, Berlin, 897 pp.

Cui, D.F. (1996) Stipa L. In: Cui, N.-R. (Ed.) Flora Xinjiangensis. Angiospermae, Monocotyledoneae, 6. Xinjiang Science \& Technology \& Hygiene Publishing House, pp. 291-313.

Čelakovský, L.F. (1884) Nachträgliches über Stipa tirsa Steven. Oesterreichische Botanische Zeitschrift. Gemeinnütziges Organ für Botanik 34: 318-321.

Dickoré, W.B. (1995) Systematische revision und chorologische analyse der Monocotyledoneae des Karakorum (Zentralasien, WestTibet). Flora Karakorumensis 1. Angiospermae, Monocotyledoneae. Stapfia 39: 1-298.

Drobov, V.P. (1941) Stipa L. In: Kudrjaschev, S.N. (Ed.) Flora Uzbekistana, 1. Academiae Scientiarum, URSS, Taschkent, pp. 179-186, 537.

Freitag, H. (1985) The genus Stipa (Gramineae) in southwest and south Asia. Notes from the Royal Botanical Garden, Edinburgh 42: 
$355-489$.

Gonzalo, R., Aedo, C. \& García, M.A. (2013) Taxonomic revision of the Eurasian Stipa subsections Stipa and Tirsae (Poaceae). Systematic Botany 38: 344-378.

http://dx.doi.org/10.1600/036364413X666615

Grisebach, A. (1852) Ptilagrostis. In: Ledebour, C.F. (Ed.) Flora Rossica sive Enumeratio Plantarum in Totius Imperii Rossici Provinciis Europaeis, Asiaticis, et Americanis Hucusque Observatarum, 4. Sttudgartiae, Sumtibus Librariae E. Schweizerbart, pp. 447-448.

Grisebach, A. (1868) Über die Gramineen Hochasiens. Nachrichten von der Königlichen Gesellschaft der Wissenschaften und von der Georg-Augusts-Universitait 3: 61-93.

Hackel, E. (1884) Gramina nova vel minus nota. Sitzungsberichte der Mathematisch-Naturwissenschaftlichen Classe der Kaiserlichen Akademie der Wissenschaften 89: 123-136.

Hackel, E. (1903) Stipa orientalis Trin. var. trichoglossa Hack. n. var. In: Paulsen, O. (Ed.) Lieutenant Olufsen's second Pamir expedition, Plants collected in Asia-Media and Persia. Videnskabelige Meddelelser fra Dansk Naturhistorisk Forening i Kjøbenhavn, 164 pp.

Handel-Mazzetti, H. (1936) Kleine Beiträge zur Kenntnis der Flora von China. Oesterreichische Botanische Zeitschrift 85: $226-227$. http://dx.doi.org/10.1007/BF01255464

Hao, K.S (1938) Pflanzengeographische Studien über den Kokonor-See und über das angrenzende Gebeit. Botanische Jahrbücher für Systematik, Pflanzengeschichte und Pflanzengeographie 68 (5): 515-668.

Hitchcock, A.S. (1930a) Fifteen new species of grasses, six from Africa, seven from China. Proceedings of the Biological Society of Washington 43: 89-96.

Hitchcock, A.S. (1930b) Stipa smithii Hitchc., sp. nov. Journal of the Washington Academy of Sciences 20: $382-383$.

Hooker, J.D. (1896) Flora of British India, 7. L. Reeve \& Co., London, 842 pp.

Kanitz, A. (1891) Novenytani Gyujtesek Eredmenyei Grof Szechenyi Bela Keletazsiai Utjabol, 1877-1880. Plantarum in Expeditione Speculatoria Comitis Bela Szechenyi a Ludovico ed Lodzy in Asia Centrali Collectarum Enumeratio. Kolozsvar, 66 pp, 7 pls.

Karelin, G.S. \& Kirilov, I.P. (1841) Enumeratio plantarum anno 1840 in regionibus altaicis et confinibus collectarum. Bulletin de la Société Impériale des Naturalistes de Moscou 4: 703-862.

Keng, Y.L. (1941a) An enumeration of grasses of Kansu Province. Sunyatsenia 6 (1): 52-76.

Keng, Y.L. (1941b) New grasses from Sikang Province. Sunyatsenia 6 (2): 77-104.

Klichowska, E. \& Nobis, M. (2016) Stipa pennata subsp. ceynowae (Poaceae) a new taxon from Central Europe. Phytotaxa (in press).

Klokov, M. \& Osychnyuk, V. (1976) Stipae Ucrainicae. Novosti Sistematiki Vysshik i Nizshikh Rastenii Kiev 1975: 7-91.

Koch, K. (1848) Beiträge zu einer flora des orientes. Linnea 21: 289-443.

Kotukhov, Yu.A. (1994) Novye vidy roda Stipa (Poaceae) iz yuzhnogo Altaya, Saura i Tarbagataya [New species of the genus Stipa (Poaceae) from south Altai, Saur and Tarbagatai]. Botanicheskii Zhurnal 79: 101-106.

Krassnov, A.N. (1887) Enumeratio plantarum anno 1886 in Tian Schan orientali lectarum. Petropoli.

Kuo, P.C. \& Sun, Y.H. (1982) A preliminary study on the classification, distribution and ecological nature of genus Stipa L. of China. Acta Phytotaxonomica Sinica 20: 34-44.

Kuo, P.C. \& Sun, Y.H. (1984) Stipa penicillata var. hirsuta. Bulletin of Botanical Research, Harbin 4 (4): 89.

Kuo, P.C. \& Sun, Y.H. (1987) Stipa Linn. In: Kuo, P.C. (Ed.) Flora Reipublicae Popularis Sinicae, 9 (3). Science Press, Beijing, pp. 268-287.

Lavrenko, E.M. (1940) Stipa L. In: Lavrenko, E.M. (Ed.) Flora URSR (Flora Reipbulicae Sovieticae Socialisticae Ucrianicae), 2. Academia Scientiarum RSS UCR. Insititutum Botanicum, Kioviae, pp. 117-131.

Linnaeus, C. (1753) Species Plantarum, 1. L. Salvii, Holmiae (Stockholm), 560 pp. http://dx.doi.org/10.5962/bhl.title.669

Linnaeus, C. (1762) Species plantarum, exhibentes plantas rite cognitas, ad genera relatas, cum differentiis specificis, nominibus trivialibus, synonymis selectis, locis natalibus, secundum systema sexuale digestas, 1, edition 2. Impensis Direct. Laurentii Salvii, Holmiæ, Stockholm, 784 pp.

http://dx.doi.org/10.5962/bhl.title.11179

Lomonosova, M.N. (1990) Stipa L. In: Malyschev, L.I. \& Peschkova, G.A. (Eds.) Flora Sibiriae, Poaceae (Graminae), 2. Divisio Sibirica, Nauka, Novosibirsk, pp. 222-230.

Lu, S.L. \& Wu, Z.L. (1996) On the geographical distribution of the genus Stipa L. in China. Acta Phytotaxonomica Sinica 34: $242-253$.

Martinovský, J.O. (1970) Stipa smithii Martinovský, eine neue Chinesische Federgrasart. XX. Beitrag zur Kenntnis der Federgrassippen. Svensk Botanisk Tidskrift 64 (2): 158-164.

Martinovský, J.O. (1975) Taxonomische Studie über die Stipa-Serie Dasyphyllae XXV. Beitrag zur Kenntnis der Gattung Stipa. Preslia 47 (3): 249-261.

Martinovský, J.O. (1980) Stipa L. In: Tutin, T.G., Heywood, V.H., Burges, N.A., Moore, D.M., Valentine, D.H., Walters, S.M. \& Webb, D.A. (Eds.) Flora Europaea, 5. Cambridge University Press, Cambridge, pp. 247-252. 
Nobis, M. (2011) Remarks on the taxonomy and nomenclature of the Stipa tianschanica complex (Poaceae), on the base of a new record for the flora of Tajikistan (central Asia). Nordic Journal of Botany 29: 194-199.

http://dx.doi.org/10.1111/j.1756-1051.2010.00869.x

Nobis, M. (2013) Taxonomic revision of the Stipa lipskyi group (Poaceae: Stipa section Smirnovia) in the Pamir Alai and Tian-Shan Mountains. Plant Systematics and Evolution 299: 1307-1354.

http://dx.doi.org/10.1007/s00606-013-0799-5

Nobis, M. (2014) Taxonomic revision of the Central Asian Stipa tianschanica complex (Poaceae) with particular reference to the epidermal micromorphology of the lemma. Folia Geobotanica 49: 283-308.

http://dx.doi.org/10.1007/s12224-013-9164-2

Nobis, M., Ebel, A.L., Nowak, A., Paszko, B., Bobrov, A.A., Kotukhov, Y.A., Kupriyanov, A.N., Nobis, A., Zalewska-Gałosz, J., Olonova, M.V., Verloove, F., Chen, V.L., Kushunina, M., Kwolek, D., Lashchinskiy, N.N., Piwowarczyk, R., Sukhorukov, A.P., Nowak, S., Plášek, V. \& Pliszko, A. (2015b) Contribution to the flora of Asian and European countries: new national and regional vascular plant records, 4. Acta Botanica Gallica 162 (4): 301-316.

http://dx.doi.org/10.1080/12538078.2015.1090329

Nobis, M., Klichowska, E., Nowak, A., Gudkova, P.D. \& Rola, K. (2016a) Multivariate morphometric analysis of the Stipa turkestanica group (Poaceae: Stipa sect. Stipa). Plant Systematics and Evolution 302 (2): 137-153.

http://dx.doi.org/10.1007/s00606-015-1243-9

Nobis, M. \& Nobis, A. (2013) Ptilagrostis milleri comb. nov. (Poaceae: Stipeae). Nordic Journal of Botany 31: $623-625$. http://dx.doi.org/10.1111/j.1756-1051.2013.00115.x

Nobis, M., Nobis, A., Nowak, A. \& Nowak, S. (2014) Stipa klimesii (Poaceae), a new species from Western Himalayas (India). Phytotaxa 174 (3): 173-180.

http://dx.doi.org/10.11646/phytotaxa.174.3.6

Nobis, M., Nowak, A., Gudkova, P.D. (2015a) A new synonym and a new combination in Stipa aliena Keng (Poaceae: Stipa sect. Regelia). Phytotaxa 195 (3): 236-242.

http://dx.doi.org/10.11646/phytotaxa.195.3.3

Nobis, M., Nowak, A. \& Nobis, A. (2013) Stipa zeravshanica sp. nov. (Poaceae), an endemic species from rocky walls of the western Pamir Alai Mountains (middle Asia). Nordic Journal of Botany 31: 666-675.

http://dx.doi.org/10.1111/j.1756-1051.2013.00184.x

Nobis, M., Nowak. A., Piwowarczyk, R., Ebel, A.L., Király, G., Kushunina, M., Sukhorukov, A.P., Chernova O.D., Kipriyanova, L.M., Paszko, B., Seregin, A.P., Zalewska-Gałosz, J., Denysenko, M., Nejfeld, P., Stebel, A., Gudkova, P.D. (2016b) Contribution to the flora of Asian and European countries: new national and regional vascular plant records, 5. Botany Letters 163 (2): $159-174$. http://dx.doi.org/10.1080/23818107.2016.1165145

Noltie, H.J. (1999) Notes relating to the flora of Bhutan: XXXVIII. Gramineae I, tribe Stipeae. Edinburgh Journal of Botany 56: 285292.

Norlindh, T. (1949) Flora of the Mongolian Steppe and desert areas. Part I. Pteridophyta, Gymnospermae and Monocotyledoneae (Typhaceae - Graminae). Tryckeri Aktiebolaget Thule, Stockholm, 155 pp.

Ohwi, J. (1943) Notes on some grasses from North China and Inner Mongolia. Journal of Japanese Botany 19: 166-171.

Paczoski, J.K. (1914) Khersonskaya flora 1. Khodusinoy, Kherson.

Pazij, V.K. (1968) Stipa L. In: Kovalevskaya, S.S. (Ed.) Opredelitel rastienii sredniei Azii (Conspectus florae Asiae Mediae) vol. 1. Editio Academiae Scientiarum UzSSR, Taschkent, pp. 64-82 \& 200-201.

Prokhudin, G.N.(1951)Zlaki[Gramineae]. In: Stankov, S.S.(Ed.) Flora Kryma, 1(4). Gosudarstwennoe Izdatel'stvo Sel'skokhozyaistvennoi literatury, Moscow, pp. 1-153.

Roshevitz, R.Yu. (1915) Stipa L. In: Fedchenko, B.A. (Ed.) Spisok ruskikh rastenii. [Suppl. 2] Izvestiya Imperatorskogo Botanicheskogo Sada Petra Velikago 14: 48-50.

Roshevitz, R.Yu. (1916) Zlaki (Gramineae). In: Fedtschenko, B.A. (Ed.) Flora Aziatskoi Rossii, 12. Pereselencheskoe Upravlenie Ministerstva Zemledeliya, pp. 1-191.

Roshevitz, R.Yu. (1920) Stipa novae Asiae centralis. Botanicheskie Materialy Gerbarya Glavnogo Botanicheskogo Sada R.S.F.S.R. 1 (6): $1-4$.

Roshevitz, R.Yu. (1924) Stipeae novae asiaticae (Novye kovyli iz Azii). Botanicheskie Materialy Gerbariya Glavnogo Botanicheskogo Sada R.S.F.S.R. 5: 11-14.

Roshevitz, R.Yu. (1929) Novye zlaki Zabaikalya [New species from Transbaikal]. Izvestya Glavnogo Botanicheskogo Sada SSSR 28: 379-380.

Roshevitz, R.Yu. (1934) Ptilagrostis Griseb., Stipa L. In: Komarov, V.L. (Ed.) Flora SSSR, 2. Editio Academiae Scientiarum URSS, Leningrad, pp. 74-112 \& 740-741. 
Roshevitz, R.Yu. (1949) Gramineae novae, V. Botanicheskie Materialy Gerbariya Botanicheskogo Instituta im. Komarova AN SSSR 11: $18-31$.

Ruprecht, F.J. (1869) Sertum Tianschanicum. In: Osten-Sacken, F. von \& Ruprecht, F.J. (Eds.) Sertum Tianschanicum, Botanische Ergebnisse einer Reise im mittleren Tian-Schan. Memoires de l'Academie Imperiale des Sciences de Saint-Petersbourg, 14 (4): $33-74$.

Schmalhausen, J. (1892) Neue pflanzernarten aus dem Kaukasus. Berichte der Deutschen Botanischen Gesellschaft 10: $284-294$.

Sljussarenko, L.P. (1963) O ukrainskikh kovylyakh iz tsikla Stipa joannis Čel. Trudy Naychno-Issledovatel'skogo Instituta Biologii $i$ Biologicheskogo Fakulteta Kharkovskogo Gosudartvennogo Universiteta im. A. M. Gor'kogo. Botanicheske raboty 37: $26-27$.

Smirnov, P.A. (1924) Stipa macroglossa P.A. Smirnow sp.n. Botanicheskie Materialy Gerbaria Glavnogo Botanicheskogo Sada R.S.F.S.R. 5:47-48.

Smirnov, P.A. (1925) Die neuen russischen Stipa-Pennata-Arten. Repertorium specierum novarum regni vegetabilis 21: $223-233$. http://dx.doi.org/10.1002/fedr.19250210806

Smirnov, P.A. (1928) Cem XVII. Gramineae Juss. Trudy Glavnogo Botanicheskogo Sada. Acta Horti Petropolitani 40: 115.

Smirnov, P.A. (1929a) Stipa glareosa P. Smirn. sp. nova hoc loco and Stipa grandis P. Smirn. sp. nova hoc loco. In: Pavlov, N.V. (Ed.) Materials on the flora of Northern and Central Mongolia brought by the botanical expeditions in 1924 and 1926. Byulleten Moskovskogo Obshchestva Ispytatelei Prirody. Otdel Biologicheskii 38 (1-2): 12-15.

Smirnov, P.A. (1929b) Neue Stipen. Repertoruim speciorum novarum regni vegetabilis 26: 264-271. http://dx.doi.org/10.1002/fedr.19290261608

Smirnov, P.A. (1930) Notulae Stipologicae. Delectus Seminum Horti Botanici Universitatis Mosquensis 1930: 15.

Smirnov, P.A. (1934) Kluch k opredeleniu kovylei SSSR. Uchenye zapiski. Moskovskii gosudarstvennyi universitet 2: 331-338.

Stewart, R.R. (1945) The grasses of northwest India. Brittonia 5 (4): 404-468. http://dx.doi.org/10.2307/2804891

Trinius, C.B. (1829) Stipa L. In: Ledebur, K.F. von (Ed.) Flora Altaica, 1. Berolini, Typis impensis G. Reimeri, pp. 80-84.

Trinius, C.B. (1835) Stipa Bungeana Trin. In: Bunge, A.L., Enumeratio Plantarum quas in China Boreali. Mémoires présentés à l'Académie impériale des Sciences de St. Petersbourg par divers Savans et dans ses assemblées 2: 144.

Trinius, C.B. \& Ruprecht, F.J. (1842) Species Graminum Stipaceorum. Typis Academiae Imperialis Scientiarum, Petropoli, 189 pp. http://dx.doi.org/10.5962/bhl.title.15631

Tzvelev, N.N. (1968) Zlaki (Gramineae). In: Grubov, V.I. (Ed.) Rastieniya Centralnoi Azii. Po materialam Botanicheskogo Instituta im. V.L. Komarova (Plantae Asiae Centralis, secus materies Instituti botanici nomine V.L. Komarovii), 4. Nauka, Leningrad, pp. 1-243 \& 12 maps.

Tzvelev, N.N. (1973) Zametki o zlakakh flory SSSR, 7-Notae de Gramineis florae URSS, 7. Novosti Sistematiki Vysshikh Rastenii 10: 79-98.

Tzvelev, N.N. (1974) Zametki o tribe Stipae Dum. semejstva zlakov (Poaceae) v SSSR-Notulae de tribu Stipae Dum. (fam. Poaceae) in URSS. Novosti Sistematiki Vysshikh Rastenii 11: 4-21.

Tzvelev, N.N. (1976) Zlaki SSSR. Nauka, Leningrad, 788 pp.

Tzvelev, N.N. (2012) Notes on the tribe Stipeae Dumort. (Poaceae). Novosti Sistematiki Vysshikh Rastenii 43: 20-29.

Wilenskii, D.G. (1921) Stipa zalesskii. Dnevn Vserossijsk Sezda Russkikh Botanikov 1: 40-41.

Wu, Y.H. \& Wang, Q.J. (1999) The grasses of Karakorum and Kunlun Mountains. Qinghai People's Publishing House, Xining, 168 pp.

Wu, Z.L. \& Phillips, S.M. (2006) Tribe Stipae. In: Wu, Z.Y., Raven, P.H. \& Hong, D.Y. (Eds.) Flora of China (Poaceae), 22. Science Press, Beijing and Missouri Botanical Garden Press, St. Louis, pp. 188-212.

Zhao, Y.Z. (1992) Two new varieties of Stipa (Gramineae) from Nei Mongol. Acta Scientiarum Naturalium Universitatis Intramongolicae 23 (4): 545-548.

Zhao, Y.Z. \& Cao, R. (1996) The endemic plants in Nei Monggol. Acta Scientiarum Naturalium Universitatis NeiMonggol 27 (2): 208 213.

Zhao, L.Q. \& Guo, K. (2011) Stipa albasiensis (Poaceae), a new species from Inner Mongolia, China. Annales Botanici Fennici 48: 522-524.

http://dx.doi.org/10.5735/085.048.0615

Zhao, N.X. \& Li, M.F. (1994) New taxa and new recording species of Gramineae from Tibet. Acta Botanica Yunnanica 16 (3): $228-230$. 